\title{
IAMJ
}

INTERNATIONAL

AYURVEDIC

MEDICAL JOURNAL

\section{RESPIRATORY REHABILITATION IN COVID-19 PATIENTS - A REVIEW ARTICLE}

\author{
Suchita G. Shrikhande ${ }^{1}$, Nirmala (Marghade) Telrandhe ${ }^{2}$, Swati Kamble ${ }^{3}$ \\ ${ }^{1}$ P.G. Scholar, Department of Sharir Kriya, BMAM, Nandanvan, Nagpur, Maharashtra, India \\ ${ }^{2}$ Professor \& H.O.D., Department of Sharir Kriya, BMAM, Nandanvan, Nagpur, Maharashtra, India \\ ${ }^{3}$ Assistant Professor, Department of Sharir Kriya, BMAM, Nandanvan, Nagpur, Maharashtra, India
}

Corresponding Author: suchitafeb25@gmail.com

https://doi.org/10.46607/iamj1908122020

(Published online: December 2020)

Open Access

(C) International Ayurvedic Medical Journal, India 2020

Article Received: 07/11/2020 - Peer Reviewed: 13/11/2020 - Accepted for Publication: 18/11/2020

Check for updates

\begin{abstract}
Respiratory diseases are increasing rapidly and drastically, the reason behind is mainly changed breathing pattern along with environmental pollution as a highly infectious respiratory tract disease like coronavirus disease 2019 (COVID-19) can cause, physical and psychological respiratory dysfunction in patients. COVID - 19affects the respiratory tract in humans, starts off with mild flu-like symptoms or no symptoms, and further progress to severe symptoms death due to ARDS and pneumonia. Therefore, pulmonary rehabilitation is crucial for both admitted and discharged patients of COVID-19. To counterattack of various disorders developed due to polluted air or other factors. Ayurveda has advised pranayama as a mode of treatment. Pranayama is the procedure of regulated breathing, giving a solution for this problem with its multi-dimensional effects. In many research works, it is found that Pranayama is having multi- systemic benefits on the body. Respiratory system is one among those beneficiary systems. Respiratory system is directly involved in the Pranayama. Rate and rhythm of respiration, lung volumes and capacities, breath holding time etc., will get significantly and positively influenced with the practice of Pranayama. To provide a general overview about the effect of various pranayama (breathing techniques) on COVID-19 infection with special reference to respiratory system. A narrative review was performed based on the available scientific literature.
\end{abstract}

Keywords: COVID 19, Pranayama, ARDS, Pneumonia. 


\section{INTRODUCTION}

COVID - 19 pandemic sweeps across the globe, it is important to understand the transmission and the effect of the virus which has made it a pandemic. COVID 19 belongs to the coronavirus family, which also includes the SARS virus (Severe Acute Respiratory Syndrome) and MERS (Middle East Respiratory Symptoms) virus. The family of Coronavirus includes virus strains that cause the common cold and flu. SARS is a novel type of virus that was reported in 2007, and like most SARS viruses, COVID - 19 primarily infects the lungs in the affected individuals and in severe cases causes' death due to ARDS and pneumonia. It is important to remember that it does not lead to ARDS and pneumonia in all the cases, which is an occurrence in most severe cases. In the majority of the cases i.e. $80 \%$ will exhibit mild symptoms, $14 \%$ will have pneumonia, $5 \%$ will suffer from septic shock and organ failure (mostly respiratory failure) and in $2 \%$ cases it will be fatal (1). Yoga is a science which has been practised in India from over thousands of years. It is one of the best lifestyle modifications which have ever been advised in the history of mankind. There are many classical paths which have been described to reach the ultimate goal of healthy life. Besides the spiritual achievements, the practice of yoga is accompanied by a number of beneficial physiological effects in the body. Pranayama is an art of controlling the life force of breath (2). It is an ancient yoga technique, a spiritual and physical practice which integrates the mind and body. Pranayama is a type of yogic practice which produces many systemic psycho-physical effects in the body, besides its specific effects on the respiratory functions. So, it has become a standard fare at health clubs and community recreation programmes. Pulmonary function tests (PFTs) are simple screening procedures which are performed by using a standardized equipment (spirometer) to measure the lung function. This test provides useful information about the levels of the lung function. The breath holding time measures the level of the threshold of the respiratory centre to the partial pressure of the carbon dioxide (Pco2) level. Lung volumes and capacities convey the condition of functional status of respiratory system in physiological as well as pathological condition (3) . Regular practice of Pranayama is found to improve the lung volumes and capacities thereby helping in prevention (4) and management of different respiratory diseases (5). Researchers have observed that the significant change in the lung functions can be brought about even with short-term yoga training (6). Practice of yoga even for a short span of 6 weeks can make significant improvements in strength and endurance of respiratory muscle (7). Effect of pranayama in improving various diseases of asthmatics has done by various researchers such as Murthy et al (8)., Kumar et al (9)., Singh et al (10)., and Jain et al (11). "Global Initiative for Obstructive Lung Disease (GOLD)" incorporated pulmonary rehabilitation into the standard treatment for patients with COPD as early as 2001 (12). Various types of yoga asanas combined with breathing exercise can benefit physiological changes in young adults. Pranayama can significantly improve the maximum inspiratory and expiratory pressures with altering the respiratory muscle strength in pulmonary function (13), chronic asthmatic (14). In prevention cardiovascular disease (15) and coronary heart disease (16) and the management of hypertension (17). It also improves the respiratory function and QoL in patients with chronic obstructive pulmonary disease (COPD) (18). However, the effect of respiratory rehabilitation in COVID-19 is unknown here an attempt is being made to explain the use and effect of pranayama in mild to moderate condition \& rehabilitation in discharge patients of current pandemic situation COVID - 19by considering the physiological changes by the practice of Pranayama.

\section{Review of Literature}

Yoga is the part of Ayurveda gives the valuable information about Pranayama (breathing techniques). Pranayama is the best procedure for proper breathing and control over mind, as stated by various Acharyas. "When the breath wonders, the mind is unsteady but when the breath is still, so mind still."- Hathyog Pradipika. Breath is the dynamic bridge between body and mind and Pranayama is one of the most important yogic practices. It is not only having psychological 
benefits, but it is having many physical benefits also (19). The word Pranayama is comprised of two components: 'prana' and 'Ayama'. 'Prana' means 'vital energy' or 'life force'. 'Ayama' is defined as 'extension' or 'expansion'. Thus, the word Pranayama means 'extension or expansion of the dimension of prana'. In the practices of Pranayama, there are four important aspects of breathing such as (1) Pūraka (inhalation), (2) Recaka (exhalation), (3) Antah kumbhaka (internal breath retention), and (4) Bahih Kumbhaka (external breath retention) (20) Pranayama is a procedure of controlling mind by controlling the Vayu (air) in inspiration and expiration (21). Pranayama is extensively explained in Hathayog Pradipika, Gherand Samhita, Bhavishyapurana, Atharvanaveda, Kausheetaki Upanishat, Sharangadhara Paddhati, Taittireeyopanishat and Manusmriti etc (22). Hathayog Pradipika and Gherand Samhita sub-divided Pranayam into 8 types like Suryabhedana, Ujjayee, Sheetalee, Bhramaree, Bhastrikaa, Sheetkaaree, Moorchaa, Plaavinee (23). All the types of Pranayama involves deep inspiration, with holding of air and deep expiration respectively which will show their influence on different physiological entities involved in respiration, thereby significantly improves the lung volumes and capacities (24).

Effects of COVID19 on Lungs: At the onset of the disease, the main manifestations of COVID19 are fatigue, fever, dry cough myalgia and dyspnoea, with less common symptoms being nasal congestion, headache, runny nose, sore throat, vomiting and diarrhoea. Severe patients often have dyspnoea and/or hypoxemia 1 week after onset, after which septic shock, Acute Respiratory Distress Syndrome (ARDS), difficult-to-correct metabolic acidosis, and coagulation dysfunction develop rapidly (25). There is a direct correlation between COVID - 19and ARDS, severe cases of COVID - 19 infection leads to ARDS and pneumonia, which can prove to be fatal for the infected individual. ARDS causes increased breathing, heart rate, dry cough, breathing difficulties. In most healthy individuals, who do not have underlying issues COVID -19 exhibits mild symptoms, which can be treated with medications and recover fast. In severe cases, where the infected person has underlying health conditions with impaired immunity COVID - 19infection can progress to severe ARDS. Once the patient progresses to ARDS, it eventually leads to pneumonia. Before understanding the severity of COVID - 19infection, it is important to understand the different stages/categories of COVID 19infection:

First category: These individuals are infected by the virus, act as carriers but may not exhibit the symptoms. These individuals are at a higher risk of spreading the virus as they might be oblivious to its presence.

Second category: Individuals with mild fever, cough, headache or possible conjunctivitis. This is due to an infection in the upper respiratory tract.

Third category: Similar to the third category, the symptoms here are more pronounced and might require hospitalization. Immediate treatment can help alleviate the symptoms and prevent a fatality.

Fourth category: this stage is fatal. In this stage severe cases of Covid 19, might lead to ARDS and pneumonia. Effect of ARDS on lungs: COVID - 19directly impacts the lungs and damages the alveoli (tiny air sacs). The function of the alveolus is to transfer oxygen to the blood vessels. These blood vessels or capillaries carry the oxygen to the RBCs (Red blood cells). the RBCs that finally deliver the oxygen to all the internal organs in the body. The virus works by damaging the wall and the lining of the alveolus and capillaries. The debris from the damage rich in plasma protein accumulates on the alveolus wall and thickens the lining. As the walls thicken, the transfer of oxygen to the red blood cells is impaired. which causes difficulty in breathing and also the lack of oxygen to the internal organs impairs the functioning of the organs. At this juncture, the body fights to increase oxygen intake. And the first response of the body is to destroy the virus and prevent its replication, but if the individual has weaker immunity then the body is unable to stop the virus, and this aggravates the crisis

Pneumonia: As the air sacs are damaged, there is an influx of liquid which is rich in inflamed cells and protein. This fluid build-up pneumonia. This further impairs the oxygen intake by the lungs and hinders the 
oxygen exchange. Due to the novelty of the COVID 19strain, this worsen condition leads to many complications like Acute Cardiac Injury, secondary injury, acute kidney injury, septic shock \& blood clots. there is no immediate treatment to directly cure pneumonia in COVID - 19patients and are mostly given supportive care. So, there is need some alternate treatment to prevent and stop the progression of fatal disease Covid 19. Thus, pranayama practice can be useful in this disease condition by improving lungs capacity (26).

Physiology of respiration (27): Breathing is the only autonomic function that can be consciously controlled and it is the key in bringing sympathetic and parasympathetic nervous system into harmony Air that is inspired through nares will pass via trachea, bronchi, bronchioles and finally end up in the alveoli, where the actual process of gaseous exchange between lungs and blood takes place (external respiration) through respiratory membrane. Again, at the level of tissues, exchange of gases takes place between blood and tissues (internal respiration).

Mechanics of respiration: Respiration occurs in two phases i.e. inspiration and expiration. During inspiration (active process) thoracic cage enlarges and lungs expand. During expiration (passive process), thoracic cage and lungs decrease in size.

Movements of Thoracic Cage: Movement of four units like thoracic lid, upper costal series, lower costal series and diaphragm causes movement of thoracic cage thereby elevation of ribs and descent of diaphragm.

Movements of lungs: During inspiration because of enlargement of thoracic cage negative pressure is increased in the thoracic cavity. It causes expansion of lungs. During expiration thoracic cage decreases in size thereby negative pressure also comes back to preinspiratory position, which compresses the lungs, air is expelled out.

- Pulmonary Compliance is the expansibility of lungs \& thorax.

- Pulmonary surfactant is the secretion of type 2 alveolar cells. It is the surface acting materials which lines the epithelial lining of alveoli and decreases the surface tension of the alveolar membrane thereby avoid the collapse of alveoli. Prostaglandins are the chemicals secreted by the parenchyma cells of lungs which reduce the bronchiolar smooth muscle tone. • Respiratory Pressures: Intra- pleural \& Intra-alveolar pressures allow the respiration phases like inspiration and expiration.

- Receptors: Stretch, Baro, Irritant, Chemo, Proprio, Pain, Thermo etc., get stimulated to different stimuli and act accordingly and does different functions.

Regulatory mechanisms: Process of respiration is under the control of two mechanisms like Chemical and Nervous mechanism. Chemical mechanism is again of two types like central and peripheral. Nervous mechanism is under the control of Medulla oblongata (Medullary) and Pons (Pontine). Medulla oblongata has two groups of neurons like Dorsal and Ventral. Pons also have 2 group of neurons - Pneumotaxic \& Apneustic. Pontine centres can control Medullary centres.

Pulmonary function tests: These are the tests conducted to know the functional status of lungs in both physiological and pathological conditions. These are of two types' static and dynamic lung function tests. Static test will be conducted to know the lung volumes and capacities in specific condition of thorax and lungs whereas dynamic tests will be conducted to know the rate of air flow into the lungs. Spirometer is the generally used method for measuring the lung volumes and capacities.

Restrictive and obstructive respiratory diseases: Diseases with difficulty in inspiration are called as restrictive diseases and diseases with difficulty in expiration are called as obstructive diseases. The reduction of pulmonary function test values especially dynamic lung function tests values is more significant in obstructive lung diseases compared to restrictive lung diseases. FEV1 and PEFR serve the purpose of differentiating between obstructive and restrictive lung diseases.

\section{DISCUSSION}

Effect of Pranayama on Lung Volumes and Capacities (28): In all the Pranayama procedures the 
only respiratory parameter that will reduce is the rate of respiration and all the other parameters including volumes and capacities will increase depending on the regularity of practice.

The reasons for the increase of respiratory parameters can be justified in the following ways:

\section{Increased volumes $\&$ capacities can be justified with the following reasoning}

A. Increased strength of respiratory musculature (29): Regular efficient usage of muscles of respiration causes their increase in bulk. Elastic \& Collagen fibres will get strengthened and extensibility will increase thereby will allow efficient contraction, improving the inspiratory and expiratory power, Cleansing of airway secretions thereby decreasing the resistance to the air flow which will aid in full and free utility of alveoli.

B. Release of lung surfactant \& prostaglandins (30): Lung inflation near to total lung capacity in Pranayama acts as a major physiological stimulus for the secretion of pulmonary surfactant and prostaglandins. Pulmonary surfactant increases the lung compliance and Prostaglandins reduce the bronchiolar smooth muscle tonicity thereby allowing more and more air to enter into lungs which leads to increase of lung volumes and capacities (31).

C. Stimulation of stretch receptors (32): Inflation of the lungs nearly to total lung capacity stimulates the stretch receptors, which reflexively relaxes smooth muscles of larynx and Trachea - bronchial tree, thereby improving the lung volumes and capacities.

D. Removal of undue tension (33) Practice of Pranayama in relaxed state of body and mind, relaxes the skeletal muscles which help the thoracic cage to relax better than before and it will also cause withdrawal of the Broncho- constrictor effect by relaxing smooth muscles of Bronchi, thereby hike in the values of pulmonary function parameters.

Madanmohan et al (34), Lakshmi J (35), Raghuraj P et al (36), Dash M (37) All these studies have explained that, during regular pranayama training, regular inspiration and expiration for prolonged period leads the lungs to inflate and deflate maximally and that it causes strengthening and increased endurance of the respiratory muscles. The stretch receptors reflex decreases the tracheobronchial smooth muscle tone activity, which leads to decreased air flow resistance and increased airway calibre, which causes the dynamic parameters of the lung function test to improve.

2. Decreased rate of respiration (38): Respiration during Pranayama practice (i.e. conscious process of respiration which is very much regulated one) is under the control of Pneumotaxic respiratory centre. Pneumotaxic centre will control the Apneustic centre which has its role in normal quite breathing. So, this regulated pattern of breathing during Pranayama may be adopted by Apneustic centre in normal quiet breathing leading to decreased rate of respiration.

3. Extended expiratory period (39): With a regular practice of Pranayama Dorsal group neurons responsible for inspiration in normal quite breathing may be inhibited by Apneustic and Pneumotaxic centres leading to extended expiratory period.

4. Increase in the voluntary breath holding time \& pulmonary function test (40): This may be due to acclimatization of the chemoreceptors of lungs to hypercapnea and hypoxia (decreased oxygen levels) or decreased responsiveness of respiratory centre or increased development of respiratory musculature leading to increased muscle endurance and delayed fatigue. The pulmonary function parameters FVC, FEV1, PEFR, FEF25-75\% and Breath holding time (BHT) were found to be significantly increased in young healthy subjects after 6 weeks of pranayama (41). These results were consistent with those of other studies which were done by Yadav A et al. (42), Upadhyay KD et al (43). and Chanavirut et al (44)

\section{CONCLUSION}

In normal shallow breathing, lung spaces are not used, whereas Regular, slow and forceful inspiration and expiration for a longer duration during the pranayama practice, helps in using lung spaces leading to strengthening of respiratory muscle, release of surfactant \& prostaglandins, stimulation of stretch receptors, release of undue tension, adaptation of regulatory mechanisms and acclimatization of chemoreceptors. Therefore, the peak expiratory flow 
rate is increased which might be an important reason for opening small airway in the lungs. It is beneficial for the improvement of lung volumes and capacities in healthy and diseased (of restrictive \& obstructive respiratory diseases). The study by K. Liu et al., Respiratory rehabilitation in elderly patients in china with "COVID-19: A randomized controlled study with 6-week respiratory rehabilitation" significantly improves respiratory function, QoL, and anxiety and depression in elderly patients with COVID-19. The reason may be that the rehabilitation training related to respiratory muscles in respiratory rehabilitation training, and respiratory muscles include intercostal muscles, enthusiastic muscles, abdominal wall muscles, etc., which play an important role in maintaining respiratory function. Hence, future studies are required in the field of Pranayama to explore its precise effect FVC, FEV1, PEFR, FEF

\section{REFERENCES}

1. https://www.narayanahealth.org/blog/how-covid-19affect-your-lungs. [Online]. [cited 20200922.

2. Mishra SP. Yoga and Ayurveda: Their alliedness and scope as positive health sciences. 2nd ed. Varanasi: Chaukhambha Sanskrit Sansthan; 1997.

3. Sembulingam K, Sembulingam P. Essentials of Medical Physiology. 6th ed. New Delhi: Jaypee brothers' medical publishers; 2012.

4. Sembulingam K, Sembulingam P. Patil YR, Sawant RS. Study of effect of Bhastrika Pranayama on pulmonary function. International research journal of pharmacy. 2012; 3(3): p. 204-207.

5. Keerthi GS, Bandi HK, Suresh M, Reddy MN. GS Keerthi, Bandi HK, M Suresh and Reddy MN. Immediate effect of Suryanadi Pranayama on pulmonary function (Ventilatory Volumes and Capacities) in Healthy Volunteers. International Journal of Medical research and Health Sciences. 2013; 2(4): p. 724-729.

6. Mulur LM, Bagali S, Khodnapur JP, Aithala M. Role of short-term yoga on pulmonary functions of young and middle-aged healthy individuals. Int J Biomed Adv Res. 2012; 3: p. 252-255.

7. Vempati R, Bijlani RL, K DK. The efficacy of a comprehensive lifestyle modification programme based on yoga in the management of bronchial asthma: A randomized controlled trial. BMC Pulm Med. 2009.

8. Murthy KJ, Sahay BK, Sitaramaraju P, Madavi S, Yogi R, Reddy VM. Effect of pranayama (rachaka, puraka and kumbhaka) on bronchial asthma. An open study. Lung India. 1984; 2: p. 187-91.

9. Kumar AK, Kumari GK, Kumari GD, Gaur K, Manocha R. Immediate effects of pranayama in airways obstruction. LUNG India. 1985; 111: p. 77-81.

10. Singh V, Wisneiewski A, Britton J, Tattersfield A. Effect of yoga breathing exercises (pranayama) on airway reactivity in subjects with asthma. Lancet. 1990; 335: p. 1381-1383.

11. Jain SC, Taludkar B. Evaluation of yoga therapy programme for patients of bronchial asthma. Singapore Med J. 1993; 34: p. 306-308.

12. Pauwels RA, Buist AS, Calverley PM, et.al. Global strategy for the diagnosis, management, and prevention of chronic obstructive pulmonary disease. NHLBI/WHO Global Initiative for Chronic Obstructive Lung Disease (GOLD) Workshop summary. Am J Respir Crit Care Med. 2001; 163: p. 1256-1276.

13. Abel LN, Lloyd LK, Willams JS. The effects of regular yoga practice on pulmonary function in healthy individuals: A literature review. J Altern Complement Med. 2013; 19: p. 185-90.

14. Effect of pranayama on respiratory muscle strength in chronic asthmatics. National Journal of Physiology, Pharmacy and Pharmacology. 2008; 8(12): p. 17001703.

15. Hartley L, Dyakova M, Holmes J, Clarke A, Lee MS, Ernst E, et al. Yoga for the primary prevention of cardiovascular disease. Cochrane Database Syst Rev. 2014; 5(CD010072).

16. Kwong JS, Lau HL, Chau PH, Woo J. Yoga for secondary prevention of coronary heart disease. Cochrane Database Syst Rev. 2015; 6(CD009506).

17. Posadzki P, Cramer H, Kuzdzal A, Ernst E, Lee MS. Yoga for hypertension: A systematic review of randomized clinical trials. Complement Ther Med. 2014; 22: p. 511-522.

18. Maki N, Sakamoto H, Takata Y, et al. Effect of respiratory rehabilitation for frail older patients with musculoskeletal disorders: a randomized controlled trial. J. Rehabil. Med. 2018; 50: p. 908-913.

19. Sudshushanth, Sudkhyati S. Effect of Pranayama on pulmonary functions- An overview. International Ayurvedic Medical Jounal. 2013; 1(2): p. 1-6.

20. Nivethitha, et al. Pranayama on cardiovascular and autonomic variables. Ancient Science of Life. 2016 Dec; 36(2): p. 72-77.

21. Rao MV. A Textbook of Swasthavritta. Reprint ed. Varanasi Varanasi: Chaukhambha Orientalia, Reprint edition; 2014.

22. Panduranga MN. Panduranga MN. Vaidyakeeya Subhashitaani Panchatantramcha. 1st ed. Hassan: Shree Publications; 2008.

23. Rao MV. Textbook of Swasthavritta Varanasi: Reprint edition, Chaukhambha Orientalia; 2014. 
24. Dinesh $\mathrm{T}$, et.al. Effect of six weeks of Kapalabhati Pranayama training on peak expiratory flow rate in young, healthy, volunteers. Scholars academic journal of bioscience. 2013; 1(4): p. 111-114.

25. H L, Liu SM, Yu XH, et. al. Coronavirus disease 2019 (COVID-19): current status and future perspectives. International Journal of Antimicrobial Agents. 2020; 55 : p. 105951.

26. https://www.narayanahealth.org/blog/how-covid-19affect-your-lung. [Online]. [cited 2020922.

27. Sembulingam K, Sembulingam P. Essentials of Medical Physiology. 6th ed. New Delhi: Jaypee brothers' medical publishers; 2012.

28. Subhalakshmi NK, Saxena SK, et.al. Immediate effect of 'Nadi-Shodhana Pranayama' on some selected parameters of Cardiovascular, pulmonary and Higher functions of brain. Thai Journal of Physiological sciences. 2015; 18(2): p. 10-16.

29. Shankarappa V, Prashanth P, Annamalai N, Malhotra V. The short-term effect of Pranayama on lung parameters. Jounal of clinical and diagnostic research. 2012; 6(1): p. 27-30.

30. Doijad V P, Surdi AD. Effect of short-term Yoga practice on pulmonary function tests. Indian Journal of basic and applied Medical Research. 2012; 1(3): p. 226230.

31. Smith A P. Prostaglandins and respiratory system prostaglandins; physiological, pharmacological and pathological aspects. Edited by SMM. Karim. 1976; p. 83-102.

32. Shankarappa V, Prashanth P, Annamalai N, Malhotra V. The short-term effect of Pranayama on lung parameters. Jounal of clinical and diagnostic research. 2012; 6(1): p. 27-30.

33. Doijad VP, Surdi AD. Effect of short-term Yoga practice on pulmonary function tests. Indian Journal of basic and applied Medical Research. 2012; 1(3): p. 226230.

34. Madanmohan, Udupa K, Bhavanani AB, Shatpathy CC, Sahai A. Immediate Effect of such pranayama on cardiovascular variables in the patients of hypertention. Indian J Physiol Pharmacol. 2004; 48(4): p. 461-465.

35. Madanmohan, Laxshmi J, Udupa K, Bhawanani AB. Effect of yoga training on handgrip, respiratory pressures and pulmonary function. Indian $\mathrm{J}$ Physiol Pharmacol. 2003; 47(4): p. 387-392.

36. Raghuraj P, Telles S. Muscle power, dexterity skill and visual perception in community home girls who were trained in yoga or sports and in regular schoolgirls. Indian J Physiol Pharmacol. 1997; 41: p. 409-415.

37. Dash M, Tells S. Yoga training and motor speed, based on a finger tapping task. Indian J Physiol Pharmacol. 1999; 43.

38. Patil YR, Sawant RS. Study of effect of Bhastrika Pranayama on pulmonary function. International research journal of pharmacy. 2012; 3(3): p. 204-207.
39. Sembulingan K, Sembulingam P. Essentials of Medical Physiology. 6th ed. New Delhi: Jaypee brothers' medical publishers; 2012.

40. Shamkarappa V, Prashanth P, Annamalai N, Malhotra V. The short-term effect of Pranayama on lung parameters. Jounal of clinical and diagnostic research. 2012; 6(1): p. 27-30.

41. Chauhan A, et al. Evaluation of the efficacy of pranayama on the lungs parameter and blood pressure of hypertensive patients. Innovare journal of ayurvedic sciences. 2013; 1(2): p. 1-5.

42. Yadav A, Savita S, Singh KP. Role of the pranayama breathing exercises in the rehabilitation of coronary artery disease patients. Indian $\mathrm{J}$ of Traditional Knowledge. 2009; 3: p. 455-508.

43. Upadhyay KD, Malhotra V, Sarkar D, Prajapati R. Effects of alternate nostril breathing exercises on the cardiorespiratory functions. Nepal medical Coll J. 2008; 10(1): p. 25-27.

44. Chanavirut R, Khaidjapho K, Jare P, Pongnaratorn P. Yoga exercise increases chest wall expansion and lung volumes in healthy Thais. Thai J Physiological sciences. 2006; 19(1): p. 1-7.

\section{Source of Support: Nil \\ Conflict of Interest: None Declared}

How to cite this URL: Suchita G. Shrikhande et al: Respiratory Rehabilitation In Covid-19 Patients - A Review Article. International Ayurvedic Medical Journal \{online\} 2020 \{cited December, 2020 $\quad$ Available from: http://www.iamj.in/posts/images/upload/5320 5326.pdf 